\title{
ASSESSMENT OF EFFICIENCY OF AN AGRICULTURAL TRACTOR ENGINE FOR DIFFERENT ROTATIONAL SPEEDS
}

\author{
Jacek WASILEWSKI ${ }^{1}$, Andrzej KURANC ${ }^{1}$, Joanna SZYSZLAK- \\ BARGLOWICZ1, Monika STOMA ${ }^{1}$, Tomasz SLOWIK ${ }^{1}$, Dalibor BARTA ${ }^{2}$ \\ ${ }^{1}$ University of Life Sciences in Lublin, POLAND \\ ${ }^{2}$ University of Zilina, SLOVAKIA \\ E-mail of corresponding author: jacek.wasilewski@up.lublin.pl
}

Key words: agricultural tractor, sustainable agriculture, compression-ignition engine, engine test stand, efficiency of engine, rotational speed

\begin{abstract}
Within the framework of this paper efficiency of the S-4003 engine Ursus C-360 tractor was evaluated in terms of variation of its rotational speed. The proper use of the engine operating parameters according to various agrotechnical conditions is consistent with the concept of sustainable agriculture, which assumes rational management and the least harm to the environment. Higher engine efficiency results in less fuel consumption. Engine tests were performed on a dynamometer bench at the engine test stand, based on load characteristics, for the speed range from the maximum torque $(1600 \mathrm{rpm})$ to the rated one $(2200$ $\mathrm{rpm}$ ), at every $150 \mathrm{rpm}$. The fuel (Ekodiesel Ultra D) calorific value was determined using the KL-12 calorimeter produced in Poland. It was found out that the highest efficiency of the tested engine was achieved for the intermediate speeds from 1750 to $1900 \mathrm{rpm}$.
\end{abstract}

\section{INTRODUCTION}

Conventional heating plants as well as thermal power plants constitute primary environmental hazards but from the point of view of anthropogenic environmental hazards, transport, especially wheeled transport is also considered to be hazardous. This primarily results from substantial consumption of fuel. Fuel consumption expenses often account for over $50 \%$ of total costs incurred by transport enterprises (Black 2002, Stead 2001, Zamboni et al. 2015). Agricultural transport (food products transport and animal husbandry transport) is strictly connected with safety and environmental protection concerns (Bauer et al. 2010, Garcia-Alvarez et al. 2013, Krautzberger and Wetzel 2012, Vanek and Sun 2008). Moreover, transport-related issues are subject to the law and related regulations in force in the European Union. This is related to the issue of competition among carriers, labour conditions. vehicle technical standards and related energy consumption (Behrends et al. 2008, Burski et al. 2016, Drewes et al. 2003).

Advancing development of the automotive market and related increase in fuel consumption rates and alongside emission of toxics contained in combustion gases cause progressive degradation of natural environment (Zając and Weqgrzyn 2008). In the case of compression-ignition engines, high concentration of pollutants caused by combustion gases is not only the case with urban agglomerations but also rural areas. This is merely this type of engine that, alongside heavy trucks, is commonly used for agricultural tractors and machinery. Catalytic combustion is the most effective way of reducing emission of gases and particulate matter contained in combustion gases. Measurable ecological benefits as well as advantageous basic engine performance indicators (fuel consumption, power output, torque) are achieved by means of intraengine „operations” such as, for instance, relevant regulations, type and features of fuel 
or engine operational parameters tailored to driving conditions (rotational speed, load) (Merkisz et al. 2005, Wasilewski and Krasowski 2015).

Sustainable agriculture promotes a rational use of natural resources at the least possible negative environmental impact. Engines of agricultural vehicles are characterized by a high degree of nuisance to the natural environment, mainly due to their inadequate technical condition, but also to the specifics of field works. Hard and diversified operational conditions in the case of agricultural tractors require operating speed, namely the most efficient ration of engine rotational speed to the load (type of operations performed) alongside lowest possible fuel consumption and highest possible rated nominal power. Therefore, efficiency, that is directly proportional to nominal power and inversely proportional to time-limited fuel consumption, is particularly significant engine performance indicator:

$$
\eta_{e}=\frac{3,6 \cdot 10^{6}}{g_{e} \cdot W}=\frac{3,6 \cdot 10^{3} \cdot N_{e}}{G_{e} \cdot W}
$$

where:

$$
\begin{aligned}
& \eta_{e}-\text { efficiency, } \\
& g e-\text { unitary fuel consumption, } \mathrm{g} / \mathrm{kWh} \text {, } \\
& \mathrm{Ge} \text { - hourly fuel consumption, } \mathrm{kg} / \mathrm{h}, \\
& \mathrm{Ne} \text { - effective power, } \mathrm{kW}, \\
& W-\text { fuel calorific value, } \mathrm{kJ} / \mathrm{kg} \text {. }
\end{aligned}
$$

In order to meet the ecological goal of sustainable agriculture, in addition to proper farming practices and the best use of the tractor engine operating parameters, there is a need to replace older agricultural tractors with newer, more economical and environmental friendly. Undoubtedly such activities are time-consuming, but as in every field of economics also in agriculture the priority is environmental protection.

\section{TEST STAND AND STUDY METHODOLOGY}

Ursus C-360 agricultural tractor's S-4003 four-cylinder engine, mounted on a dynamometer bench at the engine test stand workshop in the Power Engineering and Means of Transport Department of the University of Natural Science in Lublin, underwent the study tests. The engine at issue has the combustion system with direct fuel injection into a toroidal cavity on the piston head. The Fig. 1 presents the study test stand diagram. 


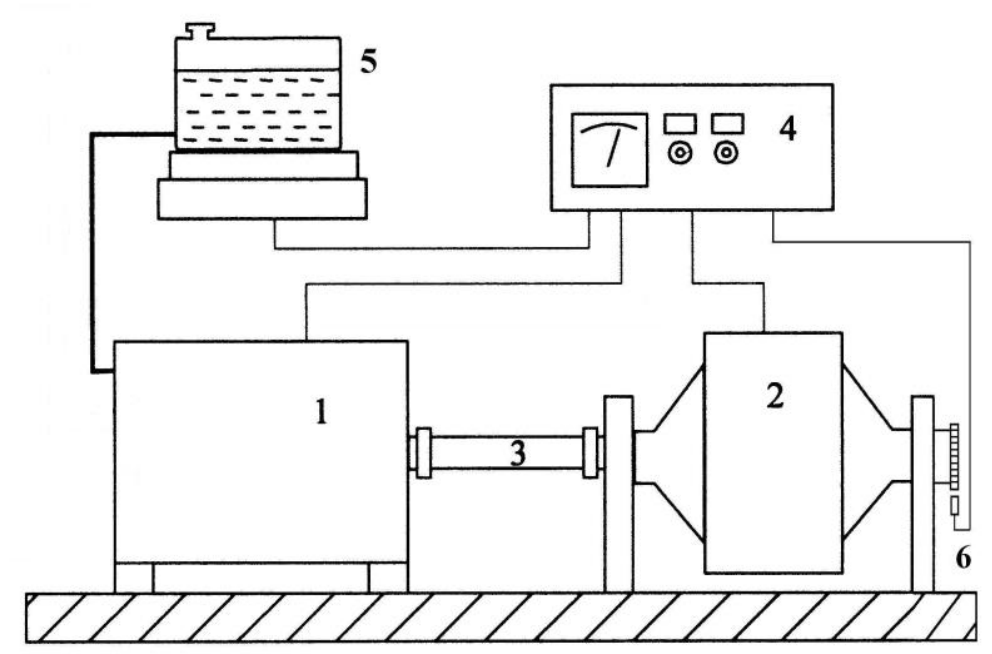

Fig. 1. The diagram of the test stand: 1 - combustion engine, 2 - electric brake, 3 - transmission shaft, 4 -control panel, 5 - fuel consumption measurement system, 6 - inductive sensor

The electric brake type K1 - $136 \mathrm{~B}-\mathrm{E}$ (asynchronous ring generator), that has also been used for switching on the ignition of the engine at issue, is the essential part of the dynamometer bench. Load variations were effectuated by changing the current for the brake switchboard through the liquid resistor.

The inductive sensor aligned with the N05 digital meter was used for measuring the rotational speed of the engine.

Fuel consumption was measured by means of weighing with the use of the electronic balance type TP-30B that allows to measure fuel dose consumption time automatically.

Calorific value of fuel, that is indispensable for computing efficiency of an engine, was defined by means of KL-12 calorimeter made in Poland.

Engine measurements were performed on the grounds on load characteristics in terms of varied rotational speed within the range from the maximum torque $(1600 \mathrm{rpm})$ to the rated speed $(2200 \mathrm{rpm})$, at every $150 \mathrm{rpm}$. In the course of defining respective load characteristics in respect of every single rotational speed, the effective power and timelimited fuel consumption were measured. Then the efficiency have been calculated following the formula 1 .

\section{STUDY RESULTS AND ANALYSIS}

The Fig. 2 presents the results of the $\eta_{e}$ efficiency experiments for S-4003 tractor's engine in the function of $N_{e}$ effective power alongside rotational speed variable, and the Table 1 theoretical relations corresponding to the aforementioned experiment resulting figures defined on the grounds of the regression analysis curve. The relevant equation formula was chosen on the basis of the value of the determination coefficient $\mathrm{R}^{2}, \mathrm{~F}$ Snedecor test functions for the purpose of testing accuracy of the model and significance levels of respective elements of the regression function ( $t$-Student's tests). 


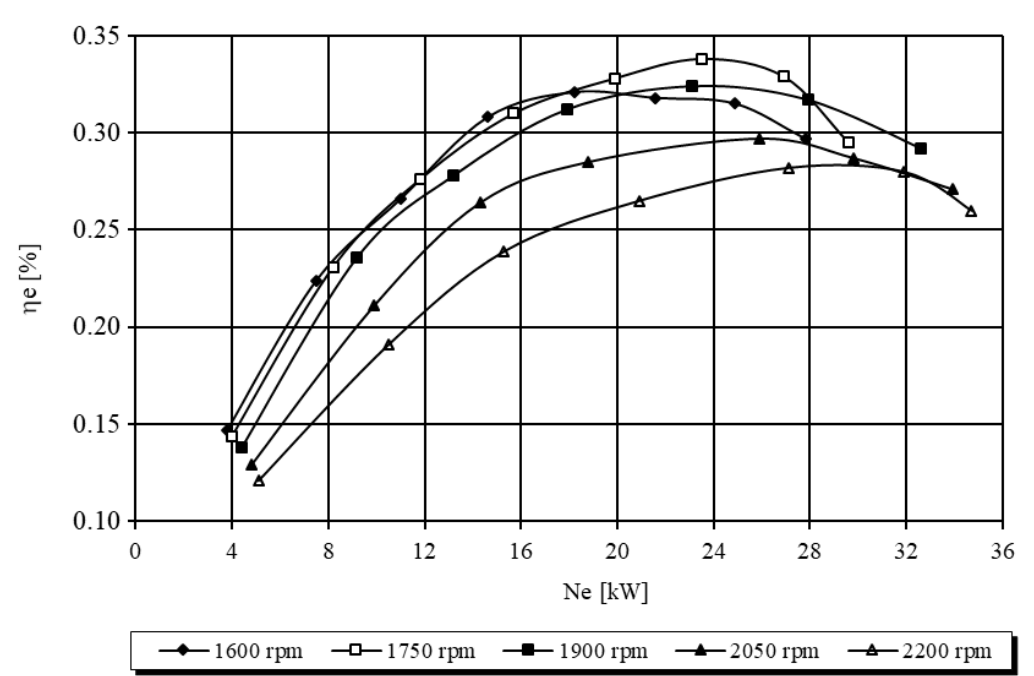

Fig. 2. Variations of efficiency $\eta_{e}$ for S-4003 engine in the function of $N_{e}$ effective power alongside rotational speed variable

Calorific value of fuel, that is indispensable for computing efficiency of an engine, was defined by means of KL-12 calorimeter made in Poland. Ultra D Ekodiesel was the fuel that underwent the study tests. Its calorific value stood at $W=42887 \mathrm{~kJ} / \mathrm{kg}$.

Table 1. Regression equation formula and $R^{2}$ determination coefficients that define efficiency $\eta_{e}$ for S4003 engine alongside varied rotational speed

\begin{tabular}{|c|c|c|}
\hline Engine rotational speed & Regression equation formula & $\begin{array}{c}R^{2} \text { Determination } \\
\text { coefficient }\end{array}$ \\
\hline $1600 \mathrm{rpm}$ & $\eta_{e}=-0.00062 N_{e}^{2}+0.025429 N_{e}+0.062816$ & 0.9952 \\
\hline $1750 \mathrm{rpm}$ & $\eta_{e}=-0.00059 N_{e}^{2}+0.025591 N_{e}+0.052261$ & 0.9936 \\
\hline $1900 \mathrm{rpm}$ & $\eta_{e}=-0.0005 N_{e}^{2}+0.023717 N_{e}+0.050387$ & 0.9919 \\
\hline $2050 \mathrm{rpm}$ & $\eta_{e}=-0.00043 N_{e}^{2}+0.021151 N_{e}+0.041336$ & 0.9929 \\
\hline $2200 \mathrm{rpm}$ & $\eta_{e}=-0.00033 N_{e}^{2}+0.017986 N_{e}+0.03843$ & 0.9967 \\
\hline
\end{tabular}

The analysis of the aforementioned relations has indicated as follows:

1. Efficiency reached the highest value to the extent of medium engine load, and it is inversely proportional to the unitary fuel consumption. Its peak values for the engine rotational speed variations under consideration to the extent of the effective power were kept within the range of $N_{e}=20-27 \mathrm{~kW}$.

2. The peak value of the efficiency of the engine under consideration within the range of the rotational speed variations from the maximum torque $(1600 \mathrm{rpm})$ to the rated speed (2200 rpm) corresponded with $1750 \mathrm{rpm}$. It amounted to $\eta_{e}=0.338$ and corresponded to the power $N_{e}=23.5 \mathrm{~kW}$.

3 . The top mean value of the operational efficiency of the engine was reached to the extent of maximum load alongside the rotational speed at $1750 \mathrm{rpm}\left(\eta_{e}=0.275\right)$, and rose by $17.3 \%$ as compared to the lowest rated speed $\left(\eta_{e}=0.234\right)$. 
4. In the case of higher load $\left(N_{e}>20 \mathrm{~kW}\right), 30 \%$ of efficiency was obtained for the speed at $1900 \mathrm{rpm}$, which was not much lower (by approximately 1.5\%) than the peak value of the efficiency.

5 . High values of the determination coefficient $\left(R^{2}>0.99\right)$ proved accurate alignment of theoretical relations with the experiment resulting figures.

\section{CONCLUSIONS}

The study has proven a considerable impact of S-4003 tractor's engine rotational speed upon the efficiency of the engine. The engine proves the peak value of the efficiency when the rotational speed is lower than the rated speed and higher than the peak torque. Higher efficiency of the engine is related to the decrease in the unitary fuel consumption (optimal operations of the engine), which is particularly required for vehicles that are operated in volatile and harsh conditions, namely tractors, among others. Tractors' engines are often operated with substantial load, for instance, in the course of extreme deep ploughing. Improving of the engine efficiency is one of the fundamental challenges that constructors of modern diesel engines are to face at. It makes them costeffective and low-emission. Such actions strictly correspond to sustainable agriculture with the least environmental harm as a priority.

\section{REFERENCES}

Bauer, J., Bektas, T., Crainic, T.G. (2010). Minimizing greenhouse gas emissions in intermodal freight transport: an application to rail service design. J. Oper. Res. Soc. 61, 530-542.

Behrends S., Lindholm M., Woxenius J. (2008). The impact of urban freight transport: a definition of sustainability from an actor's perspective. Transport. Plan. Technol., 31(6), 693-700.

Black, W. R. (2002). Sustainable transport and potential mobility. Eur. J. Trans. Infrastruct. Res., 2 (3-4), 179-196.

Burski, Z., Mijalska-Szewczak, I., Wasilewsk,i J., Szczepanik, M. (2016). Evaluation of energy consumption of vehicles in EU Trans-European Transport Network. Transportation Research Part A 92, 120-130.

Drewes, N., Jaspersen, H., Petersen, T. (2003). Freight transport growth - a theoretical and methodological framework. Eur. J. Oper. Res. 144, 295-305.

García-Álvarez, A., Pérez-Martínez, P. J., González-Franco, I. (2013). Energy consumption and carbon dioxide emissions in rail and road freight transport in Spain: a case study of car carriers and bulk petrochemicals. J. Intell. Transport. Syst., Technol., Plan., Oper. 17 (3), 233-244.

Krautzberger, L., Wetzel, H. (2012). Transport and $\mathrm{CO}_{2}$ : productivity growth and carbon dioxide emissions in the European commercial transport industry. Environ. Resource Econ. 53 (3), 435-454.

Merkisz J., Piekarski W., Słowik T. (2005). Motoryzacyjne zanieczyszczenia środowiska. Wyd. Akademii Rolniczej w Lublinie. Lublin, 17-22.

Stead, D. (2001). Transport intensity in Europe - indicators and trends. Transport Policy, 8(1), $29-46$. Vanek, F., Sun, Y. (2008). Transportation versus perishability in life cycle energy consumption: a case study of the temperature-controlled food product supply chain. Transport. Res. Part D: Trans. Environ. 13 (6), 383-391.

Wasilewski J., Krasowski E. (2015). Tłokowe silniki spalinowe. Wydawnictwo Uniwersytetu Przyrodniczego w Lublinie. Lublin, 25-40, 48-53.

Zając G., Węgrzyn A. (2008). Analysis of Work Parameters Changes of Diesel Engine Powered With Diesel Fuel and FAEE Blends. Eksploatacja i Niezawodnosc - Maintenance and Reliability 2 (38), s. 17-24. Zamboni, G., André, M., Roveda, A., Capobianco, M. (2015). Experimental evaluation of Heavy Duty Vehicle speed patterns in urban and port areas and estimation of their fuel consumption and exhaust emissions. Transport. Res. Part D 35, 1-10. 